\title{
STUDIES ON NEOTROPICAL POMPILIDAE (HYMENOPTERA). X. SUPPLEMENTARY NOTES*
}

\author{
BY HOWARD E. EVANS
}

Department of Zoology and Entomology

Colorado State University, Fort Collins, Colorado 80523

The neotropical region contains a rich and exciting fauna of pompilid wasps, reviewed in a very preliminary way by Banks (1946, 1947). It was my original intention to expand upon and improve Banks' treatment, and toward this end I initiated a series of papers covering small segments of the fauna (Evans, 19651973b; see bibliography). The difficulties proved so great that I now propose to conclude this series with the present paper. The types of a great many species are in Europe or in South America, and even a recent trip to Buenos Aires was (due to a variety of unforeseen circumstances) unproductive from this point of view. Furthermore, at least three Latin American countries have recently passed laws making the exportation of specimens difficult. Hence it seems to me wise to leave the field to a younger person with more time, money, and fortitude than I possess.

The present paper includes species description and distributional notes supplementary to various papers in this series and also to my revision of the Mexican and Centrál American Pompilinal (Evans, 1966b). References to the previous 9 papers in this series are included in the bibliography.

\section{Mystacagenia albiceps Evans}

I described Mystacagenia in $1973 \mathrm{~b}$ to include three species, each known from a single female. Thus, the discovery of a single additional specimen is of interest. This is a female $M$. albiceps which agrees closely with the type of that species although from a very different locality. It was collected by $\mathrm{M}$. Alvarenga at Jacareacanga, Para, Brazil, in December, 1968 [Canad. Nat. Coll., Ottawa]. The type is from near Marcapata, Peru.

*Manuscript received by the editor January 26, 1977. 
Anoplius (Arachnophroctonus) cteniphagus new species

Holotype. - , MEXICO: VerACRUZ: Fortin de las Flores, 3350' elevation, 20 Aug. 1967 (R. E. Leech) (Wasp dragging stunned ctenid spider, Ciupinnius foliatus P.-C. \&) [Canad. Nat. Coll., Ottawa].

Description of female type. - Length $20 \mathrm{~mm}$; fore wing 18 $\mathrm{mm}$. Black, pubescence wholly dark and with strong bluish reflections; wings dark brown, with bluish reflections. Head clothed with long, dark hair, including clypeus and scape; thorax also with dense, rather long, dark hair on dorsum and pleura, propodeum especially densely hairy; coxae strongly hairy, femora with somewhat shorter and sparser hairs; first tergite densely hairy anteriorly, tergites 2-3 with some short hair, 4-5 more densely hairy, 6 with dense, stout bristles; all sternites moderately hairy. Clypeus $2.5 \times$ as wide as its median height, with a large, arcuate median emargination. Middle interocular distance 0.55 $\times$ head width; inner eye margins strongly convergent above, upper interocular distance only $0.72 \times$ lower interocular distance. Ocelli in a very compact triangle, ocello-ocular line $1.5 \times$ postocellar line. Antennae extremely long and slender, third segment $1.5 \times$ as long as upper interocular distance. Pronotum short, very broadly angulate behind; postnotum a narrow transverse band; propodeum sloping evenly in profile, median line not impressed. Front basitarsus with 3 pecten spines, the spines about twice as long as width of tarsus. Marginal cell removed from wing tip by much less than its own length; second submarginal cell rhomboidal, $1.8 \times$ as wide as high; third submarginal cell slightly wider and higher than second, narrowed by about half above.

Remarks. - Known only from the type. Dr. Leech sent me this specimen several years ago, and I have held it hoping additional specimens would come to light. None have, but I felt the species worth describing because of the unusual prey record. The dense hair and emarginate clypeus suggest Lophopompilus, but because of the angulate pronotum I think it more likely that the species belongs in Arachophroctonus. Its closest relative may be echinatus Fox, known from northern South America north to Costa Rica. However, echinatus is a somewhat smaller 
and much less hairy species with the clypeal emargination much less pronounced.

\section{Genus EPIPOMPILUS Kohl}

I reviewed the neotropical species of this genus in 1967; subsequently, I reviewed the species occurring in the Australian region (1972). This is an archaic genus with a southern hemisphere distribution. Some of the Australian and New Guinea species have unusual structural features, such as the loss of either the first or third intercubital vein, leaving only 2 submarginal cells. I describe below the first American species with only two submarginals, a brilliantly colored species from Jamaica. Two new species from Bolivia are also described, and E. nigribasis is reported from the West Indies for the first time. The number of neotropical species now stands at 16;33 are known from the Australian region.

Epipompilus jamaicensis new species

Holotype. - q, JAmAiCA: Hardwar Gap, 4000', 29 July, 1966, (Howden \& Becker) [Canad. Nat. Coll., Ottawa].

Description of type female. - Length $5.8 \mathrm{~mm}$; fore wing 5.1 $\mathrm{mm}$. Head ferruginous except occiput black, mouthparts largely straw-colored; thorax and propodeum ferruginous except black ventrally, including propleura and extreme lower parts of mesoand metapleura; abdomen fuscous, except tergites 2 and 5 each with a pair of large white spots; antennae dull ferruginous, darkened at each joint; legs varicolored, coxae black and straw-colored, femora dark brown, blotched with straw, tibiae and tarsi brown, hind tibiae annulated with straw near base. Wings mainly hyaline, fore wing with a brown band crossing wing at basal vein and a broader band at marginal cell, apex of wing with a whitish bloom; hind wing slightly infuscated apically. Clypeus broadly emarginate. Malar space slightly shorter than width of mandibles at their base. Front narrow, middle interocular line $0.53 \times$ head width; upper and lower interocular lines subequal; eyes densely hairy; ocelli in a flat triangle, postocellar line $1.2 \times$ ocello-ocular line. Third antennal segment $0.48 \times$ upper interocular line. Postnotum a very narrow transverse band; slope of propodeum low and even, median line not impressed. Front femora not swollen, 
measuring $2.9 \times$ as long as wide; tibiae wholly without spines. Fore wing with transverse median vein considerably basad of origin of basal vein; radial vein strongly angled at junction of second intercubital vein (first intercubital absent, resulting in a very long first submarginal cell); second submarginal cell slightly wider than high; hind wing with transverse median vein erect, forming a right angle with anal vein, meeting media far basad of origin of cubitus; anal lobe extremely small.

Remarks. - This striking form resembles mostly closely the Central American species insolitus Evans and delicatus Turner. It differs not only in the possession of only two submarginal cells, but also in having the head ferruginous, the postnotum extremely short, and the tibiae wholly without spines.

\section{Epipompilus quinquenotatus new species}

Holotype. - o, Bolivia: Santa Cruz: Est. Experimental Gral. Saavedra, 7 July 1973 (C. Porter, L. Stange, E. Demarest) [Inst. Miguel Lillo, Tucumán, Argentina].

Description of type female. - Length $9.6 \mathrm{~mm}$; fore wing 7.0 $\mathrm{mm}$. Head black, except palpi dark brown, mandibles rufotestaceous on apical two-thirds, scape with a large white spot on upper surface apically; thorax and propodeum entirely rufous except propleura black; abdomen black except for large paired white spots on tergites 2 and 5 and a median white spot on 6; legs variegated, coxae mainly black but with some white apically, middle and hind pair rufous basally; femora black except front and middle pair streaked with rufous; tibiae black except front pair rufotestaceous on inner surface, middle and hind pair spotted with white near base; tarsi fuscous. Fore wings strongly twice-banded, a broad band crossing wing at basal vein and another at marginal cell, membrane tinged with yellowish basally and between the two bands, at tip of wing more whitish; hind wing subhyaline, slightly darker apically. Clypeus broadly concave apically. Malar space about $0.4 \times$ as long as width of mandibles at their base. Front narrow, middle interocular distance $0.55 \times$ head width; upper interocular distance $1.1 \times$ lower interocular; eyes densely hairy; postocellar line $1.3 \times$ ocello-ocular line. Third antennal segment $0.54 \times$ upper interocular distance. Postnotum medially about half as long as metanotum; slope of 
propodeum low and even, median line not impressed. Front femora not swollen, $2.9 \times$ as long as wide; hind tibiae with scattered minute spines which do not protrude above the coarse pubescence. Fore wing with transverse median vein slightly beyond origin of basal vein; radial vein nearly evenly arcuate; second submarginal cell $1.25 \times$ as wide as high, third submarginal cell $1.5 \times$ as wide as its maximum height; hind wing with transverse median vein strongly oblique, meeting media well basad of origin of cubitus; anal lobe very small.

Allotype. - $\delta$, same data as type [Inst. Miguel Lillo, Tucumán, Argentina].

Description of allotype male. - Length $5.6 \mathrm{~mm}$; fore wing $5.0 \mathrm{~mm}$. Head black except lower inner orbits white, clypeus white except mediobasally, mouthparts mainly straw-colored; thorax and propodeum shining black, finely punctate, pronotum with a broad white band along posterior margin, mesoscutum and scutellum with median white spots; abdomen black, shining, a pair of large white spots on tergite 2 barely connected medially; antennae dark brown below, black above; front coxae strawcolored except black on basal 0.2, front legs otherwise ferruginous except tarsi becoming fuscous apically; middle legs ferruginous except basal third of coxae and all of trochanters black, outer side of tibiae and all of tarsi fuscous, spurs whitish; hind coxae black except apical third white, trochanters black, femora ferruginous suffused with black; tibiae black with a white basal spot; spurs fuscous; tarsi fuscous, segments 2-4 broadly annulated with white. Wings hyaline, apical third of fore wing faintly clouded. Clypeus $1.9 \times$ as wide as high, emarginate apically. Middle interocular distance $0.60 \times$ head width; inner eye margins diverging above; vertex forming an even arc above eye tops. Postocellar line $1.1 \times$ ocello-ocular line. Eyes not hairy. Front shining, uniformly punctate. First four antennal segments in a ratio of 11:4:7:8, segment three $1.7 \times$ as long as wide. Pronotum subarcuate behind; mesoscutum shining, uniformly punctate; scutellum with finer and closer punctures; postnotum dorsally about as long as metanotum; propodeum with median line well impressed. Claws weakly dentate except front pair bifid, outer claws of front tarsus strongly curved; hind tibiae with numerous spines extending above the coarse pubescence. Fore wing with basal and transverse median veins interstitial, other venational 
features as in female. Subgenital plate tapering to a sharp point, somewhat hirsute, as figured for delicatus Turner by Evans, 1966b, Fig. 63. Genitalia also like those of delicatus (Ibid, Fig. 60) except parameres more elongate, equal in length to parapenial lobes and digiti.

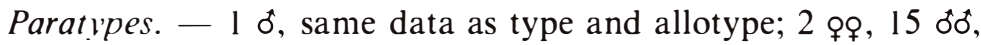
same data except various dates Jan., Feb., Aug,-Oct. 1973-74 Malaise trap, Porter \& Stange) [Inst. Miguel Lillo, Mus. Comp. Zool., Coll. C. C. Porter].

Variation. - The female paratypes resemble the type closely, but in both the spots on tergite 5 are narrowly connected medially. The males vary in length from 3.5 to $6.0 \mathrm{~mm}$. The pale spot on the scutellum is present in all males, but that on the mesoscutum is reduced or absent in the smaller specimens. The spots on tergite 2 are very small in several males and entirely absent in two; but one male has a broad, pale band on tergite two and small spots on tergite three. Leg color is also somewhat variable.

Remarks. - The females run to delicatus Turner in my 1967 key, but differ from that species in the narrower front and in lacking any trace of rufous on the abdomen, as well as in several other details of color pattern. The males run to the couplet separating delicatus Turner and tucumanus Evans but the genitalia differ from either of those species and the pattern of white spots is distinctive.

\section{Epipompilus morosus new species}

Holotype. - , Bolivia: Santa Cruz: Est. Experimental Gral. Saavedra, Sept. 1973 (C. Porter \& L. Stange, Malaise trap) [Inst. Miguel Lillo, Tucumán, Argentina].

Description of type female. - Length $9.0 \mathrm{~mm}$; fore wing 7.7 $\mathrm{mm}$. Head black except lower front and face rufous, fading to testaceous at the clypeus, malar space, and mandibles; palpi light brown; scape rufotestaceous, flagellum dull rufous, annulated with fuscous at joints; thorax black except ivory-white as follows: collar, streaks at extreme lower sides and at posterior lobes of pronotum, extreme posterior angles of propodeum; abdomen shining black, marked with whitish as follows: large lateral spots on tergite 2, small spots on 3, spots of irregular shape on 4-6, large spots on sternite 2 connected medially; front legs 
bright rufous except coxae mostly black, tarsi weakly infuscated; middle and hind legs black except coxae white at apices, tibiae spotted with white near the base, spurs whitish. Wings hyaline, fore wings with a weak band at the basal vein and a weak spot at the second and third submarginal cells. Clypeus arcuately concave. Malar space $0.6 \times$ as long as width of mandibles at their base. Front broad, middle interocular distance $0.61 \times$ head width; upper interocular distance $0.94 \times$ lower interocular; eyes densely hairy; postocellar line twice the ocello-ocular line. Third antennal segment $0.48 \times$ upper interocular distance. Pronotum moderately long, broadly angulate behind; postnotum a very narrow band; propodeum sloping evenly in profile. Front femora $2.6 \times$ as long as wide; hind tibia with only very minute spines. Fore wing with transverse median vein located very slightly basad of basal vein; radial vein strongly angulate at second intercubital vein; maximum width of third submarginal cell $1.45 \times$ that of second submarginal; hind wing as in preceding species.

Remarks. - This species is known only from the type, which is quite unlike any other species of the genus. It is a member of the azteca species-group, and will run to couplet 5 of my 1967 key, separating inca Evans and jocosus Evans. The wing venation is very similar to that of those two species, but the banding is much weaker; there are important differences in body color from both species. E. inca is a larger species, with the postocellar line only $1.6 \times$ the ocello-ocular line and the postnotum more broadly exposed, while E. jocosus has the postnotum concealed dorsally and the tibiae more evidently spinose.

\section{Epipompilus tucumanus Evans}

I described this species in 1967 from a series from Argentina as well as one female from Venezuela. A single female was collected in Bolivia by Porter, Stange, and Demarest, at Buena Vista, Dept. Santa Cruz, 8-26 July, 1973 [Coll. C. C. Porter].

\section{Epipompilus nigribasis (Banks)}

I have reported this very small species from Panama, Colombia, and Brazil. In the Canadian National Collection there is a pair from Canuaru, Pernambuco, Brazil, collected in April, 1972, by $\mathrm{M}$. Alvarenga. Porter and Stange have also collected this 
species Malaise traps in Bolivia: $20^{\circ}$, Est. Experimental Gral. Saavedra, Aug. 1973 and Jan. 1974. I am also able to report the species from the West Indies for the first time: 10 , Bar del Isle, St. Lucia, Lesser Antilles, 20 Oct. 1935 (H. E. Box) [British Museum (Natural History)]. Thus three species of this genus are now known from the West Indies: nigribasis (Banks), jamaicensis Evans, and pulcherrimus Evans.

\section{REFERENCES}

BANKS, $\mathrm{N}$.

1946. Studies of South American Psammocharidae. Part I. Bull Mus. Comp. Zool., 96: 311-525.

1947. [Same title]. Part II. Bull. Mus. Comp. Zool., 99: 371-486.

Evans, H. E.

1965. Studies on neotropical Pompilidae (Hymenoptera), I. The genus Agenioideus Ashmead in South America. Breviora, Mus. Comp. Zool., No. 234, 7 pp.

1966a. [Same title]. II. Genus Aridestus Banks. Psyche, 73: 116-122.

1966b. A revision of the Mexican and Central American spider wasps of the subfamily Pompilinae (Hymenoptera: Pompilidae). Mem. Amer. Ent. Soc., No. 20, 442 pp., 11 pls.

1967. Studies on neotropical Pompilidae (Hymenoptera). III. Additional notes on Epipompilus Kohl. Breviora, Mus. Comp. Żool., No. 273, $15 \mathrm{pp}$.

1968. [Same title]. IV. Examples of dual sex-limited mimicry in Chirodamus. Psyche, 75: 1-22.

1969a. [Same title]. V. Austrochares Banks. Psyche, 76: 18-28.

1969b. [Same title]. VI. Dicranoplius Haupt. Studia Ent., 12: 383-400.

1969c. [Same title]. VII. Irenangelus Schulz. Studia Ent., 12: 417-431.

1972. Revision of the Australian and New Guinean species of Epipompilus (Hymenoptera: Pompilidae). Pacific Insects, 14: 101-131.

1973a. Studies on neotropical Pompilidae. VIII. The genus Aporus Spinola in South America. Studia Ent., 16: 353-370.

1973b. [Same title]. IX. The genera of Auplopodini. Psyche, 80: 212-226. 


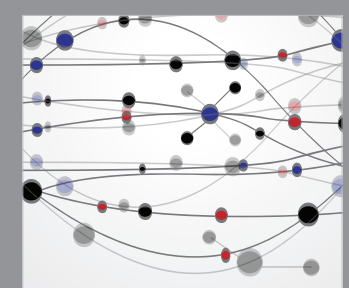

The Scientific World Journal
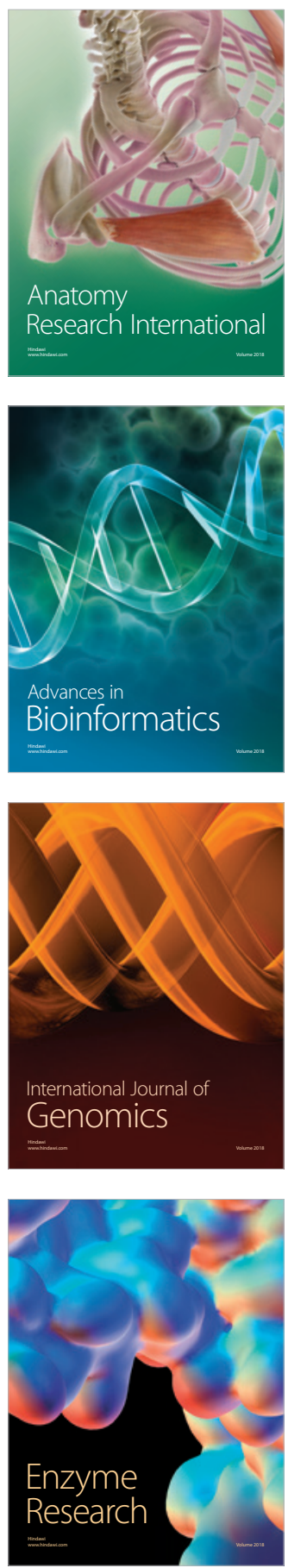
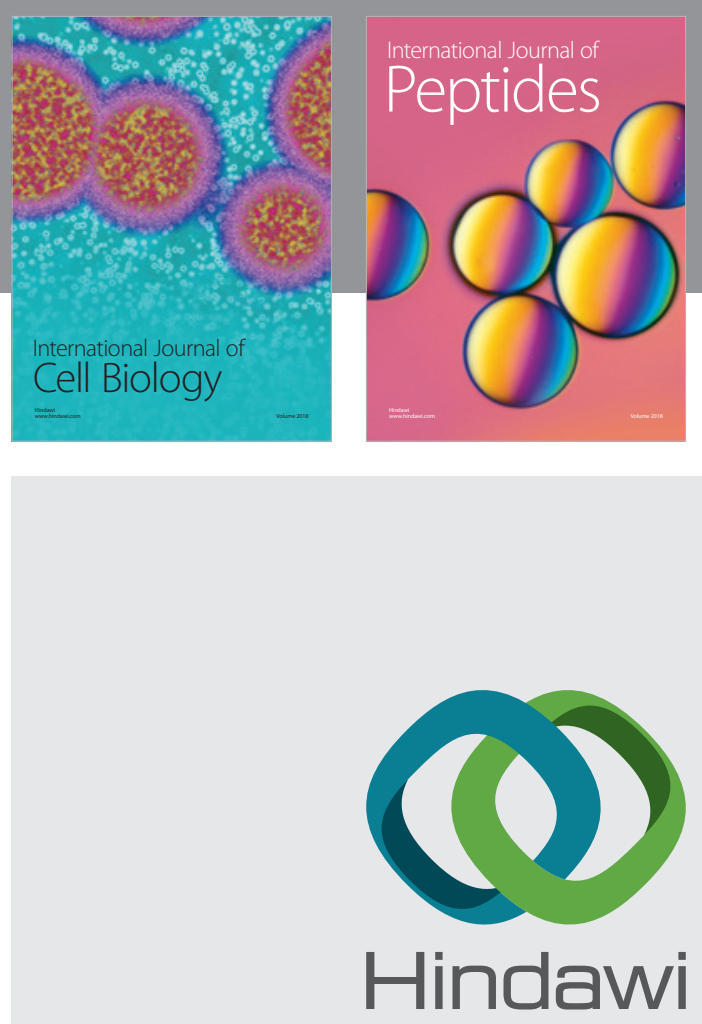

Submit your manuscripts at

www.hindawi.com
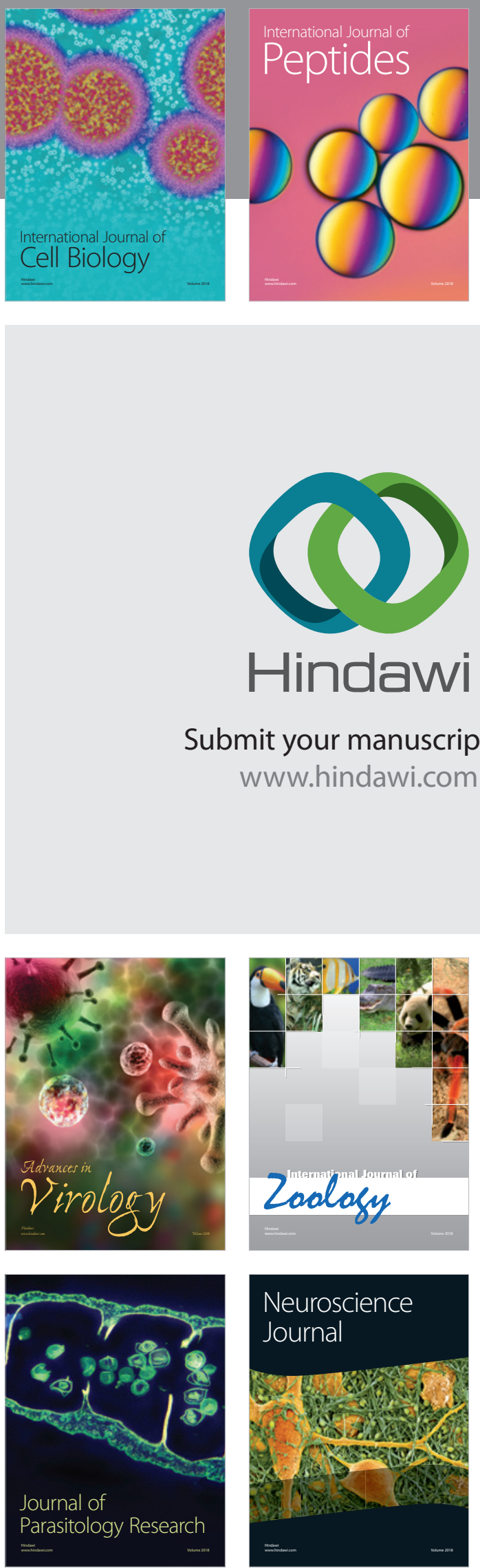
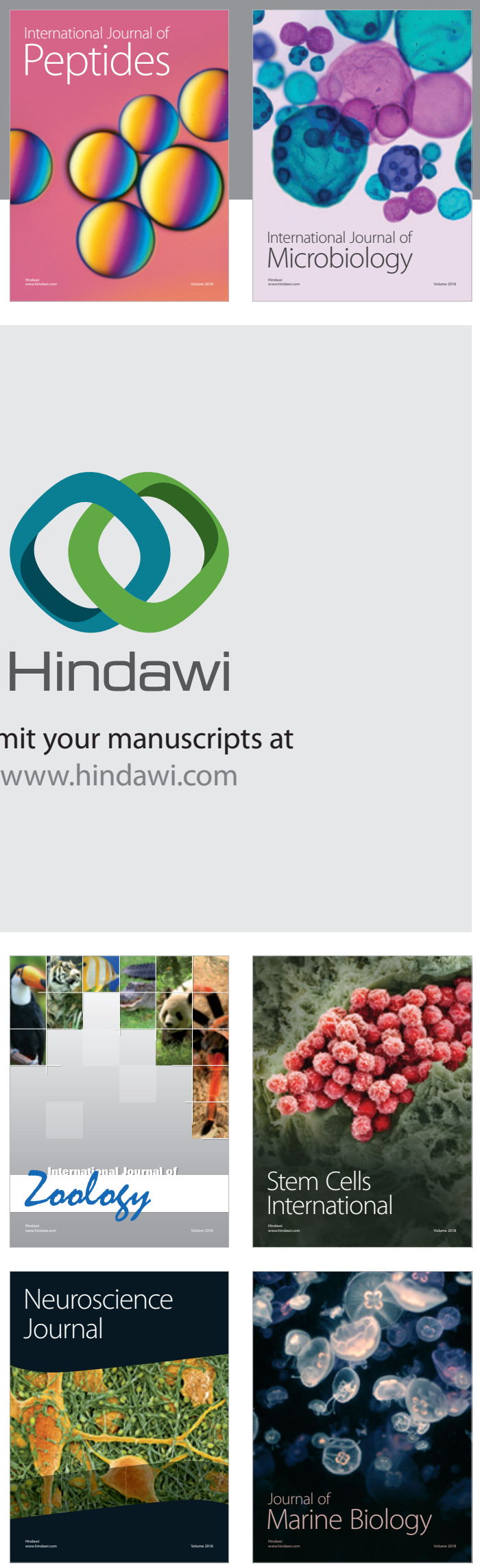
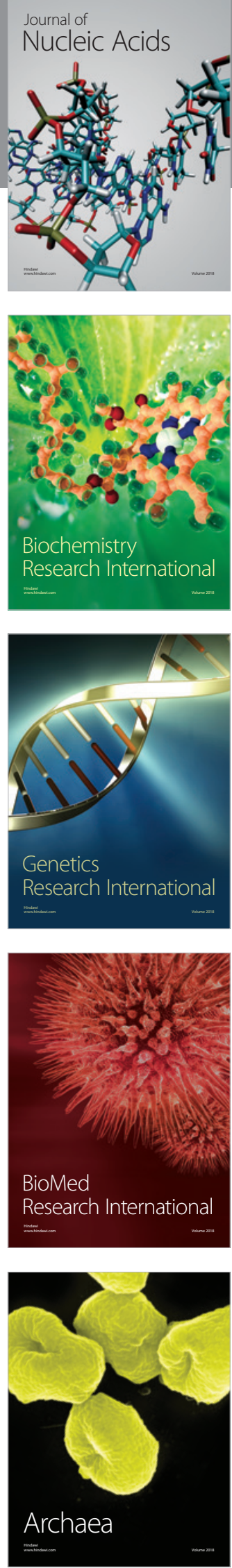